\title{
DA MUTAÇÃO CONSTITUCIONAL AO ATIVISMO JUDICIAL: Uma Análise do Entendimento do Supremo Tribunal Federal Sobre Prisão em Segunda Instância
}

\author{
http://dx.doi.org/10.21527/2176-6622.2020.54.232-245
}

Recebido em: 15/1/2020

Modificações solicitadas em: 20/4/2020

Aceito em: 6/4/2020

\section{RESUMO}

\section{Andréia Carvalho de Sousa}

Bacharel em Direito pelo Centro Universitário Uninovafapi (Uninovafapi). http://lattes.cnpq br/4206240916412461. https://orcid.org/0000-0001-6931-3249. andreiacs_16@hotmail.com

\section{Macell Cunha Leitõo}

Doutor em Direito e mestre em Teoria, História e Filosofia do Direito pela Universidade Federal de Santa Catarina (PPGD/UFSC). Bacharel em Direito pela Universidade Estadual do Piauí (Uespi). Professor do Centro Universitário Uninovafapi e do Instituto de Ensino Superior (Icev). http://lattes.cnpq.br/0874951812504064. https:// orcid.org/0000-0003-3213-6263. macellbr@hotmail.com

O discurso de combate à criminalidade presente na esfera pública brasileira tem fomentado o debate sobre a admissibilidade da prisão após a condenação em segunda instância e, por conseguinte, a problemática jurídica acerca do princípio constitucional da presunção de inocência. Diante desse contexto, o presente trabalho buscou investigar os limites à mutação constitucional para verificar em que medida a interpretação do Supremo Tribunal Federal, que flexibiliza a garantia fundamental de presunção de inocência, consiste numa prática de ativismo judicial. Para tanto, foi realizada revisão bibliográfica sobre o tema, bem como a análise dos Habeas Corpus 126.292 e 152.752 e das Ações Declaratórias de Constitucionalidade 43 e 44. A investigação detectou que a mutação constitucional que autoriza a prisão antes do trânsito em julgado de sentença penal condenatória consiste em uma perversão de um instituto que busca preservar a supremacia e a força normativa da Constituição. Nesse caso, evidenciada como prática de ativismo judicial que extrapola os limites interpretativos do texto normativo, a mutação revela-se inconstitucional, pois contrária ao núcleo fundamental do Estado Democrático de Direito. Os resultados desse estudo implicam a crítica aos argumentos consequencialistas que levam à suspensão de direitos e garantias constitucionais por razões de segurança e de efetividade.

Palavras-chave: Mutação constitucional. Ativismo judicial. Prisão em segunda instância. Presunção de inocência. Supremo Tribunal Federal.

FROM CONSTITUTIONAL MUTATION TO JUDICIAL ACTIVISM:

\section{AN ANALYSIS OF THE BRAZILIAN SUPREME COURT UNDERSTANDING ON PRISON IN THE SECOND INSTANCE}

\section{ABSTRACT}

The discourse against criminality that is present in the Brazilian public sphere has fomented the debate about the admissibility of the prison after the condemnation in the second instance and, consequently, the legal problematic about the constitutional principle of the presumption of innocence. Given this context, the present work sought to investigate the limits to the constitutional mutation to verify on what extent the interpretation of the Brazilian Supreme Court that flexibilizes the fundamental guarantee of presumption of innocence consists in the practice of judicial activism. To this end, a literature review was conducted on the subject, as well as the analysis of Habeas Corpus 126.292 and 152.752 and Declaratory Actions of Constitutionality 43 and 44 . The investigation showed that the constitutional mutation that authorizes the prison before the final judgment of a condemnation is a perversion of an institute that seeks to preserve the supremacy and the normative force of the Constitution. In this case, it was evidenced as a practice of judicial activism that goes beyond the interpretative limits of the normative text, the mutation is unconstitutional, as it is contrary to the fundamental core of the Rule of Law. The results of this study imply criticism of the consequentialist arguments that lead to the suspension of constitutional rights and guarantees for reasons of security and effectiveness.

Keywords: Constitutional mutation. Judicial activism. Prison in the second instance. Presumption of innocence. Brazilian Supreme Court.

\section{SUMÁRIO}

1 Introdução. 2 A tensão entre a mudança constitucional e a preservação da supremacia e da força normativa da Constituição. 3 Limites da interpretação da Constituição: da mutação constitucional ao ativismo judicial. 4 Prisão em segunda instância e os entendimentos do Supremo Tribunal Federal. 4.10 princípio da presunção de inocência ou da não culpabilidade. 4.2 Posicionamentos do Supremo Tribunal Federal quanto à admissibilidade da prisão em segunda instância. 4.30 julgamento do Supremo Tribunal Federal sobre prisão em segunda instância em sede de controle concentrado e abstrato. 5 Considerações finais. 6 Referências. 


\section{INTRODUÇÃO}

Nos últimos anos o Brasil tem vivenciado um aumento progressivo do discurso de combate à criminalidade. De acordo com o argumento em voga em debates políticos e midiáticos, parcela significativa dos problemas nacionais está relacionada com uma cultura de desrespeito à lei que prospera diante da leniência das instâncias repressoras estatais no combate à corrupção e à violência. A propagação desse diagnóstico tem ampliado o clamor popular por reformas institucionais que tornem os instrumentos de controle penal mais céleres e efetivos, associando - inclusive as garantias constitucionais - como óbices ao processo de moralização que supostamente tem ocorrido no país.

Dentro desse conjunto de reformas, que se caracteriza nitidamente por seu populismo penal (RUIZ, 2018), os membros da Operação Lava Jato e seus apoiadores militam pela admissibilidade e pela necessidade de execução da prisão após condenação em segunda instância, provocando o debate sobre o princípio da presunção de inocência estabelecido na Constituição Federal que determina que ninguém será considerado culpado até o esgotamento das possibilidades recursais de sentença penal condenatória. Esse contexto não apenas promoveu sucessivas mutações constitucionais acerca da matéria no Supremo Tribunal Federal, como permanece em discussão a possibilidade de nova mutação por meio de iniciativas legislativas em tramitação na Câmara dos Deputados e no Senado Federal. Sem ignorar, é claro, que essas pretensas alterações de dispositivos legais e/ou constitucionais venham a originar outra judicialização acerca do tema.

Diante desse cenário, o presente trabalho busca investigar os limites à mutação constitucional com o objetivo de verificar em que medida a interpretação do Supremo Tribunal Federal que flexibiliza a garantia fundamental de presunção de inocência pode ser caracterizada como autêntica prática de ativismo judicial. A metodologia da pesquisa está pautada na revisão bibliográfica sobre o tema, bem como na análise das decisões judiciais da Corte Suprema que modificaram o sentido constitucional acerca da admissibilidade da prisão após condenação em segunda instância, quais sejam, os Habeas Corpus 126.292 e 152.752 e as Ações Declaratórias de Constitucionalidade 43 e 44.

Como forma de alcançar esse objetivo geral, o artigo está estruturado da seguinte maneira. 0 momento inicial analisa o conceito de mutação constitucional de modo a apontar que esse mecanismo de alteração informal da Constituição carrega consigo uma tensão entre a adaptação das normas constitucionais e a preservação da supremacia e da força normativa da Constituição. Posteriormente o trabalho investiga os limites apontados pela teoria jurídica à mutação constitucional para que a sua realização pelo órgão jurisdicional responsável por realizar a guarda da Constituição não consista em ativismo judicial contrário ao núcleo fundamental instituído pelo poder constituinte originário. Por fim, é analisado propriamente o princípio constitucional da presunção de inocência e alguns dos principais argumentos que fundamentaram os diferentes posicionamentos dos ministros do Supremo Tribunal Federal acerca da admissibilidade da prisão em segunda instância.

A hipótese da pesquisa, confirmada ao longo da investigação, é que a flexibilização da presunção de inocência pelo Supremo Tribunal Federal consiste em prática de ativismo judicial que extrapola os limites interpretativos do texto normativo, configurando, nesse caso, uma mutação inconstitucional, pois contrária ao núcleo fundamental do Estado Democrático de Direito. Assim sendo, a autorização da prisão antes do trânsito em julgado de sentença penal condenatória configura uma perversão de um instituto que visa exatamente a preservar a supremacia e a força normativa da Constituição.

\section{A TENSÃO ENTRE A MUDANÇA CONSTITUCIONAL E A PRESERVAÇÃO DA SUPREMACIA E DA FORÇA NORMATIVA DA CONSTITUIÇÃO}

As formas como uma Constituição pode ser alterada constituem um tema que invoca o debate acerca das limitações às possibilidades de transformação do núcleo de sentido estabelecido pelo poder constituinte originário, pois seus diferentes processos de mudança devem permitir a adaptação das normas constitucionais sem comprometer a supremacia e a força normativa da Carta Magna. A finalidade básica desses mecanismos é assegurar a estabilidade dos conteúdos éticos fundamentais positivados no texto constitucional. 
A supremacia constitucional define a Constituição como a norma superior do ordenamento, de modo que acima dela não exista nenhuma norma positiva. ${ }^{1}$ Isto ocorre devido ao fato de que o reconhecimento da existência das mutações não pode gerar questionamentos quanto à superioridade da Constituição como sua principal característica e garantidora da ordem jurídica de um país (VEGA, 1999).

O princípio da supremacia da Constituição consiste, portanto, em um preceito basilar do sistema jurídico nacional, sendo responsável por conferir validade e por legitimar os poderes estatais, na medida em que reconhece e distribui as diferentes atribuições a serem exercidas pelos poderes constituídos. Deste princípio decorre a hierarquia das normas, a partir da norma constitucional, por intermédio do controle de constitucionalidade, que verifica a compatibilidade das normas que compõem o sistema jurídico (SILVA, 2002).

Isso implica que as mutações constitucionais podem coexistir com o princípio da supremacia constitucional, desde que não deturpem o fundamento de validade do próprio ordenamento jurídico. O problema dos limites da mutação constitucional aparece quando a relação entre viabilidade e normatividade adquire um caráter conflituoso, seja social, política ou juridicamente, pondo em xeque a supremacia constitucional. Por essa razão, as restrições a esta forma de atualização constitucional devem ser encontradas no respeito à Constituição, que constitui a expressão máxima e solene da soberania nacional e popular, bem como na necessidade de adaptação social das normas constitucionais às exigências sociais atuais (VEGA, 1999; TEIXEIRA, 1991).

Não por acaso, a mutação constitucional está intrinsecamente relacionada à preservação da força normativa da Constituição, pois a preservação da efetividade das disposições constitucionais depende da adaptação das suas normas à realidade de determinado momento histórico. Essa ideia é desenvolvida pela teoria concretista ${ }^{2}$ de Konrad Hesse (1991, p. 20-21), para quem

[q]uanto mais o conteúdo de uma Constituição lograr corresponder à natureza singular do presente, tanto mais seguro há de ser o desenvolvimento de sua força normativa. Tal como acentuado, constitui requisito essencial da força normativa da Constituição que ela leve em conta não só os elementos sociais, políticos e econômicos dominantes, mas também que, principalmente, incorpore o estado espiritual (geistige Situation) de seu tempo. Isso lhe há de assegurar, enquanto ordem adequada e justa, o apoio e a defesa da consciência geral. Afigura-se, igualmente, indispensável que a Constituição mostre-se em condições de adaptar-se a uma eventual mudança dessas condicionantes.

A mutação constitucional atua como meio para a aproximação entre a Constituição e a realidade constitucional em que a mesma se encontra inserida. Por meio da interpretação correlacionada entre todos os aspectos sociais, políticos e econômicos de um povo é possível o entendimento de suas reais necessidades e assim sua adequação ao texto constitucional, garantindo uma adequada e justa interpretação e consequente força normativa a tal mudança informal da Constituição. Quando, porém, levar em consideração somente um destes aspectos, deixando de correlacioná-los entre si, tal mutação não desempenhará seu papel de aproximação, fazendo com que a força normativa da Carta Magna diminua, colocando em xeque sua supremacia e até mesmo sua existência.

Desta forma, a mutação constitucional está ligada à existência de uma Constituição dotada de força normativa. Para que esta ocorra, ela deve ser tanto normativa quanto permitir sua dinamicidade. Nesse ínterim, a sua força normativa desempenha o papel de conformação da vida em sociedade e o caso concreto será o responsável por conferir dinamicidade às normas constitucionais.

Por conter as diretivas superiores do arranjo político e jurídico de uma nação, a Constituição só se estabilizará e produzirá os resultados pertinentes na proporção em que for possível a sua adequação às novas realidades da vida social.

\footnotetext{
1 Em sua Teoria Pura do Direito, Hans Kelsen (2006, p. 24) explica que a norma hipotética fundamental - que constitui o fundamento de validade das normas que integram o sistema jurídico - consiste em uma norma pressuposta pelo pensamento jurídico. Deste modo, a Constituição consiste efetivamente na norma posta superior do ordenamento jurídico estatal.

2 Sobre o contexto de surgimento da teoria de Konrad Hesse ver SOUZA NETO; SARMENTO, 2017, p. 192-195.
} 
A ideia de Constituição normativa impõe que as normas constitucionais sejam encarregadas por conformar a realidade. Nesse sentido, é imprescindível harmonizar o mundo fático e o normativo com o intuito de que não haja qualquer eufemismo à supremacia da Constituição, uma vez que o fático não pode exceder o normativo. Assim sendo, torna-se fundamental que a mutação constitucional fique circunscrita aos limites normativos concebidos pela própria Constituição para que não configure um ativismo judicial. ${ }^{3}$

\section{LIMITES DA INTERPRETAÇÃO DA CONSTITUIÇÃO: Da Mutação Constitucional ao Ativismo Judicial}

As formas de realização da mutação constitucional devem ser estudadas tendo como ponto de partida a observação da vivência constitucional. Em decorrência da informalidade concedida a esse processo, não tem como ser tachado com a finalidade de esvaziar-se em um rol com todas as possibilidades em que poderiam ocorrer as mutações constitucionais.

Segundo Uadi Lammêgo Bulos (1997), mutação constitucional pode ser ocasionada por interpretação, por construção judicial, por complementações legislativas, por usos e costumes, por práticas governamentais, judiciárias e legislativas, e ainda por influência dos grupos de pressão. ${ }^{4}$ Paolo Ruffia (1984, p. 233-234) explica, nesse sentido, sobre o conceito de mutação constitucional:

Importa sublinhar como freqüentemente, mesmo não variando a letra escrita da Constituição, modifica-se sensivelmente a situação jurídica configurada pela mesma no sentido de que as leis ordinárias (no seu âmbito de validade), os costumes (enquanto idôneos para atuar em matéria constitucional), as sentenças da magistratura (sobretudo nos Estados anglo-saxões) e as regras de correção constitucional podem transformar, substancialmente, a realidade da vida constitucional, quando vem afirmado pelas mesmas normas constitucionais (fenômeno expressivamente definido pelos alemães com o termo Verfassungswandlung, no sentido de mudança de algum princípio do sistema constitucional vigente, em contraposição com a Verfassungsänderung, no sentido de revisão da letra escrita da Constituição).

A questão central sobre este tema envolve a necessidade de limitar a forma como as mutações constitucionais podem ocorrer, pois se, por um lado, é imprescindível a adequação da Constituição com a realidade da sociedade - sem a qual ela corre o risco de se tornar, como diria Lassale (2015), uma "mera folha de papel" - por outro, essa alteração não pode retirar a força normativa do núcleo fundamental da Carta que constitui o fundamento último de validade do ordenamento jurídico estatal..$^{5}$ Em outras palavras, a preservação da força normativa da Constituição exige a adaptação de suas normas para a preservação de sua identidade constitucional. Como, porém, estabelecer limites a esse mecanismo de modificação informal?

\footnotetext{
3 Apesar de o presente trabalho ter como objeto de estudo a mutação constitucional que se opera por meio da interpretação judicial, é importante explicitar que esse mecanismo informal de mudança da Constituição é levado a efeito pelos três poderes do Estado. Conforme explica Luis Roberto Barroso (2018, p. 165), "é fora de dúvida que o legislador e o administrador têm sua atuação fundada na Constituição, precisando interpretá-la na rotina de suas funções. De fato, é nela que deverão colher os princípios inspiradores de sua conduta e os fins a serem realizados com sua atividade". Por essa razão, o referido autor sistematiza a mutação constitucional em: interpretação (judicial e administrativa), atuação do legislador e costumes. Ver, nesse sentido, BARROSO, 2018, p. 165-173.

4 Acerca dos grupos de pressão, Uadi Lammêgo Bulos (1997, p. 66-67) pontua que "[n]as sociedades hodiernas, devido ao fato de refletirem a estrutura econômica, social, política, religiosa, cultural, são retratos fiéis das grandes paixões, provenientes de aspirações corporativas, que se desdobram em núcleos de configuração e finalidades inconfundíveis. [...] Os grupos de pressão, portanto, que têm sido objeto de numerosos estudos e investigações, em todas as suas modalidades e técnicas de ação, afirmam-se como uma realidade inegável em nossos dias, independentemente de convicções pessoais e idiossincrasias. [...] No Brasil, embora não esteja prevista na legislação, é manifesta a atividade dos grupos de pressão, não raro sob o impulso dos partidos políticos, das categorias profissionais, de trabalhadores ou de servidores públicos, das organizações econômicas, privadas e públicas, das instituições de classes liberais, militantes da defesa do meio ambiente, enfim, dos patronos de diferentes interesses, que agem, fortemente, em favor de teses e reivindicações".

5 Clèmerson Clève e Bruno Lorenzetto (2015, p. 141) reforçam esse entendimento ao afirmarem que "[a] hierarquia normativa, a rigidez constitucional e guardiões da Constituição assentados em uma Corte Suprema não são dispositivos que buscam uma simples estabilização e imobilização social, ao contrário, são institutos jurídicos orientados para a preservação de valores estimados como fundamentais para a comunidade política e que, por isso, adquirem status jurídico privilegiado no ordenamento normativo. A Constituição e suas cláusulas pétreas podem ser vistos, assim, como limites à mutação constitucional, em especial, em sua modalidade silenciosa".
} 
Em sua Hermenêutica Crítica do Direito, Lenio Luiz Streck afirma que, mesmo com o reconhecimento da tese que diferencia norma e texto, não é possível atribuir qualquer sentido ao texto constitucional. ${ }^{6}$ Streck (2004, p. 131) destaca ainda a relação existente entre texto e norma ao esclarecer:

A afirmação "a norma é (sempre) produto da interpretação do texto", ou que o "intérprete sempre atribui sentido (Sinngebung) ao texto", nem de longe pode significar a possibilidade deste - o intérprete - poder dizer "qualquer coisa sobre qualquer coisa", atribuindo sentidos de forma arbitrária aos textos, como se texto e norma estivessem separados (e, portanto, tivessem "existência" autônoma).

Quer dizer, mesmo que o intérprete busque atribuir um sentido condizente com a realidade social, econômica e política da sociedade, o texto normativo, no caso o texto constitucional, atua como limite fundante das possibilidades decisórias. Assim, sendo a Constituição expressão do poder constituinte originário, a mutação constitucional tem como parâmetro os limites por ele imposto.

Essa ideia já estava contida na tese acima referida de Konrad Hesse (1991), para quem só se pode falar em mutação constitucional desde que não exista a ruptura entre o ordenamento jurídico e a realidade fática, fazendo-se necessário que se estabeleça um equilíbrio entre as normas e o contexto histórico no qual elas estão inseridas. Uma vez que para que a Constituição mantenha sua força normativa faz-se indispensável sua correlação com as condições históricas das quais teve origem, tido que a partir do momento em que se separa de seu contexto histórico, ela passa a perder seus efeitos de norma fundamental de uma sociedade. Frise-se, porém: tampouco cabe ao intérprete autêntico do texto constitucional - mesmo sob a pretensão de exercício do papel de "guardião da Constituição"7 - usurpar o sentido instituído pelo poder (constituinte) que, como tal, atribuiu-lhe a condição de poder constituído.

Desse modo, a ausência de limites na interpretação judicial da Constituição não se coaduna com o Estado Democrático de Direito, podendo configurar o fenômeno conhecido por ativismo judicial. Luís Roberto Barroso argumenta sobre esse tema que, em um primeiro momento, o ativismo judicial foi uma reação conservadora da Suprema Corte Norte-Americana, gerando conflitos até mesmo com o então presidente dos Estados Unidos da América.

Foi na atuação proativa da Suprema Corte que os setores mais reacionários encontraram amparo para a segregação racial (Dred Scott X Sanford, 1857) e para a invalidação das leis sociais em geral (Era Lochner, 19051937), culminando no confronto entre o presidente Roosevelt e a Corte, com a mudança da orientação jurisprudencial contrária ao intervencionismo estatal (West Coast X Parrish, 1937) (BARROSO, 2012, p. 7).

Esse entendimento conservador, todavia, adotou paulatinamente um caráter aparentemente progressista, à medida que o ativismo judicial começa a ser adotado como estratégia de proteção dos direitos das minorias, que não conseguiam fazer valer suas demandas por meio dos mecanismos majoritários da democracia constitucional. Não por acaso, o ativismo judicial divide, até hoje, opiniões no campo jurídico, havendo desde aqueles que o entendem como uma prática que extrapola as funções do poder Judiciário, até mesmo os estudiosos que o consideram como uma forma de alcançar o fim do formalismo imposto pelo Estado Liberal em que o juiz teria unicamente o papel de aplicar mecanicamente a norma abstrata a um caso concreto. Existem ainda aqueles que, de maneira simplista, julgam essa corrente como "boa" por introduzir mais "humanidade" às decisões judiciais (BARROSO, 2012).

Do ponto de vista institucional, o ativismo judicial consiste também em fonte de conflito entre os poderes Executivo, Legislativo e Judiciário. Um dos principais argumentos utilizados para criticá-lo costuma invocar o fato de os membros das instâncias judiciais não serem escolhidos diretamente pelo povo, carecendo de legitimidade popular para adentrar nas competências e atribuições dos poderes escolhidos mediante sufrágio

\footnotetext{
6 A concepção de que o texto normativo é indeterminado e que, portanto, a norma jurídica é produzida a partir de um ato de interpretação está presente, em maior ou menor grau e de diferentes maneiras, nas diferentes teorias jurídicas do século 20. Ver, nesse sentido, COSTA, 2008.

7 Para análises empíricas sobre o exercício e a justificação do papel de guardião da Constituição exercido pelo Supremo Tribunal Federal, ver GARCIA, 2008, e CERQUEIRA NETO, 2016.
} 
universal. Ao que se contrapõe, em geral, a ideia de que a maior intervenção do Judiciário na política e na sociedade decorre do aumento exponencial de demandas judiciais da própria população, insatisfeita com as ações e omissões dos órgãos administrativos e legislativos.

Apesar de o exercício do controle judicial de constitucionalidade não possa ser confundido com ativismo judicial, alguns dados sobre as ações de constitucionalidade julgadas em sede de controle concentrado pelo Supremo Tribunal Federal permitem antever a ampliação e até mesmo a relativa centralidade do poder decisório do Judiciário na atual democracia constitucional brasileira.

Tabela 1 - Processos autuados anteriormente a 2000

\begin{tabular}{ccccc}
\hline & ADC & ADI & ADO & ADPF \\
\hline 1988 & 0 & 11 & 0 & 0 \\
1989 & 0 & 159 & 0 & 0 \\
1990 & 0 & 255 & 0 & 0 \\
1991 & 0 & 232 & 0 & 0 \\
1992 & 0 & 166 & 0 & 0 \\
1993 & 1 & 162 & 0 & 0 \\
1994 & 0 & 198 & 0 & 0 \\
1995 & 0 & 210 & 0 & 0 \\
1996 & 0 & 159 & 0 & 0 \\
1997 & 3 & 206 & 0 & 0 \\
1998 & 2 & 181 & 0 & 0 \\
1999 & 2 & 189 & 0 & 0 \\
\hline Soma: & 8 & 2.128 & 0 & 0 \\
\hline
\end{tabular}

Fonte: Supremo Tribunal Federal - Estatísticas de Ações do Controle Concentrado (BRASIL, 2019).

Tabela 2 - Processos autuados a partir de 2000

\begin{tabular}{ccccc}
\hline & ADC & ADI & ADO & ADPF \\
\hline 2000 & 0 & 253 & 0 & 10 \\
2001 & 1 & 210 & 0 & 16 \\
2002 & 0 & 206 & 0 & 10 \\
2003 & 0 & 308 & 0 & 10 \\
2004 & 1 & 277 & 0 & 16 \\
2005 & 1 & 265 & 0 & 24 \\
2006 & 3 & 195 & 0 & 20 \\
2007 & 5 & 159 & 0 & 21 \\
2008 & 2 & 178 & 5 & 32 \\
2009 & 4 & 177 & 3 & 44 \\
2010 & 3 & 152 & 3 & 18 \\
2011 & 4 & 163 & 6 & 20 \\
2012 & 0 & 180 & 3 & 25 \\
2013 & 0 & 189 & 4 & 34 \\
2014 & 2 & 112 & 3 & 15 \\
2015 & 6 & 230 & 7 & 48 \\
2016 & 6 & 194 & 1 & 59 \\
2017 & 6 & 237 & 9 & 68 \\
2018 & 8 & 178 & 5 & 54 \\
2019 & 2 & 93 & 1 & 29 \\
\hline Soma: & 54 & 3.956 & 50 & 573 \\
\hline
\end{tabular}

Fonte: Supremo Tribunal Federal - Estatísticas de Ações do Controle Concentrado (BRASIL, 2019). 
Conforme se pode perceber, nos anos 2000 ocorre um crescimento exponencial de processos autuados que demandam à Suprema Corte brasileira a análise da compatibilidade de leis e de atos normativos com as regras e princípios instituídos na Carta Magna. Em parte esse fenômeno está relacionado com a ampliação significativa do rol de legitimados para a propositura dessas ações, nos termos estabelecidos pela própria Constituição Federal de 1988 e, claro, pelo uso estratégico que os diferentes atores sociais e políticos passaram a fazer das disposições constitucionais como forma de luta pelo direito. ${ }^{8}$ É inegável, contudo, atribuir parcela desse resultado à postura ativista dos órgãos judiciais, mormente, aqui considerado, do próprio Supremo Tribunal Federal. Este fato levou Oscar Vilhena Vieira (2008) a cunhar a expressão "supremocracia" para designar a expansão da autoridade do Supremo em relação às demais instâncias judiciais e, até mesmo, em detrimento dos demais poderes. ${ }^{9}$

O ativismo judicial representa, assim, um processo de reiterada desconsideração e de intervenção nas decisões tomadas pelos outros poderes, de modo que o Judiciário avoca para si o papel de legislador, sob o pretexto de que as normas possuem ampla margem interpretativa. Segundo Luís Roberto Barroso (2012), apesar de a doutrina ainda não ter estabelecido um critério de distinção das decisões pautadas no ativismo judicial, três condutas podem ser apontadas como manifestações de tal ideia: (a) aplicação direta da Constituição a situações não expressamente contempladas em seu texto e em atividade independente do legislador; (b) declaração de inconstitucionalidade de atos normativos emanados do legislador, com base em critérios menos rígidos que os de patente e ostensiva violação da Constituição e (c) imposição de condutas ou de abstenções ao poder público, notadamente em matéria de políticas públicas.

Conforme se pode perceber, o ativismo judicial como abuso do poder de interpretação das normas constitucionais pode significar, em determinados casos, que a mutação constitucional contrarie o seu propósito de preservar a força normativa e a supremacia da identidade constitucional. Nesse sentido, Elival da Silva Ramos (2013, p. 141) afirma:

Se, por meio de exercício ativista, se distorce, de algum modo, o sentido do dispositivo constitucional aplicado (por interpretação descolada dos limites textuais, por atribuição de efeitos com ele incompatíveis ou que devesse ser sopesados por outro poder etc.) está o órgão judiciário deformando a obra do próprio Poder Constituinte originário e perpetrando autêntica mutação inconstitucional, prática essa cuja gravidade fala por si só.

Dessa forma, em determinados casos, a mutação constitucional pode deixar de ser um simples mecanismo de alteração informal da Constituição para se tornar um dispositivo de legitimação do ativismo judicial que contraria o cerne do próprio constitucionalismo. Essa situação torna-se ainda mais patente quando a mudança das normas constitucionais por intermédio da interpretação judicial, ao invés de proteger os direitos das minorias, contraria os direitos fundamentais individuais estabelecidos no texto constitucional. É o que tem ocorrido no debate, ainda existente no cenário jurídico brasileiro, sobre a constitucionalidade da prisão após a condenação em segunda instância.

\footnotetext{
8 Ingo Sarlet, Guilherme Marinoni e Daniel Mitidiero (2018, p. 989-990) explicam que "[a] ação direta de inconstitucionalidade, antes deferida exclusivamente ao Procurador-Geral da República, foi potencializada. Passaram a ter legitimidade à propositura da ação direta de inconstitucionalidade, para o controle abstrato de norma ou de omissão, (i) o Presidente da República; (ii) a Mesa do Senado Federal; (iii) a Mesa da Câmara dos Deputados; (iv) a Mesa da Assembleia Legislativa ou da Câmara Legislativa do Distrito Federal; (v) o Governador do Estado ou do Distrito Federal; (vi) o Procurador-Geral da República; (vii) o Conselho Federal da Ordem dos Advogados do Brasil; (viii) partido político com representação no Congresso Nacional e (ix) confederação sindical ou entidade de classe de âmbito nacional (art. 103 da (F)". Os referidos autores mencionam, ainda, a arguição de descumprimento de preceito fundamental, a ação declaratória de constitucionalidade, a representação interventiva, entre outros. (Idem, p. 990) Sobre as diferentes estratégias de disputa do poder judiciário, conferir CARDOSO; FANTI, 2013.

9 O presente trabalho não tem por escopo analisar em profundidade as causas ou mesmo as consequências do ativismo judicial. Para uma discussão sobre esse fenômeno na realidade brasileira ver BENVINDO, 2014.
} 


\section{PRISÃO EM SEGUNDA INSTÂNCIA E OS ENTENDIMENTOS DO SUPREMO TRIBUNAL FEDERAL}

O Supremo Tribunal Federal, no ano de 2009, ao revisar sua jurisprudência deliberou, quando do julgamento do Habeas Corpus no 84.078-7/MG, pelo impedimento do cumprimento antecipado da pena, uma vez que, em virtude da norma contida na Constituição Federal, a presunção de inocência deveria prevalecer até o momento em que fosse declarado o trânsito em julgado da sentença penal condenatória, não sendo permitida, nesse caso, a prisão do acusado, com exceção se contidos os pressupostos de prisão cautelar.

Em 2016, todavia, a mesma Suprema Corte brasileira, no julgamento do Habeas Corpus no 126.292/SP, afastou esse entendimento que já estava consolidado, desde o ano de 2009, e julgou que a execução provisória de acórdão prolatado em recurso de apelação, ainda que sujeito a recurso especial ou extraordinário, não iria ao encontro do princípio da presunção de inocência previsto na Constituição Federal de $1988 .^{10}$

Verifica-se a partir dos julgados que o principal argumento que embasou a fixação da referida tese é o fato de as decisões em duplo grau de jurisdição formarem coisa julgada singular, isso porque a dupla análise do mérito depreende o esgotamento de provas e fatos.

Em outubro do mesmo ano o Partido Nacional Ecológico e o Conselho Federal da Ordem dos Advogados do Brasil deram entrada nas Ações Declaratórias de Constitucionalidade nos 43 e 44, pedindo a concessão da medida cautelar para suspender a execução antecipada da pena de todos os acórdãos prolatados em segunda instância. Alegaram que o julgamento do Habeas Corpus no 126.292/SP, em fevereiro daquele ano, no qual o Supremo Tribunal Federal entendeu possível a execução provisória da pena, vinha gerando grande controvérsia jurisprudencial acerca do princípio constitucional da presunção de inocência, porque, mesmo sem força vinculante, tribunais de todo o país estavam adotando idêntico posicionamento, produzindo uma série de decisões que, deliberadamente, ignoram o disposto no artigo 283 do Código de Processo Penal.

O pedido constante nas Ações Declaratórias de Constitucionalidade era para que o Supremo Tribunal Federal reconhecesse a constitucionalidade do artigo 283 do Código de Processo Penal, invalidando, assim, o pronunciamento do Plenário de fevereiro de 2016. O referido artigo diz que, antes de haver o trânsito em julgado, ninguém poderá ser preso fora dos casos de prisão em flagrante ou por aplicação de medida cautelar. Prisão como status de condenação penal só após esgotados todos os recursos cabíveis.

Ambas as ações têm como relator o ministro Marco Aurélio, que, durante o julgamento das medidas cautelares, teve seu voto vencido na discussão que terminou em outubro de 2016. Prevaleceu o entendimento do ministro Luiz Edson Fachin de que após a condenação em segunda instância a pena de prisão já pode ser cumprida em caráter antecipado, apesar de o artigo 5o, inciso LVII, da Constituição Federal de 1988, destacar que "ninguém será considerado culpado até o trânsito em julgado de sentença penal condenatória".

Por maioria de votos, em abril de 2018 o Plenário do Supremo negou o Habeas Corpus no 152.752, por meio do qual a defesa do ex-presidente Luiz Inácio Lula da Silva buscava impossibilitar a execução antecipada da pena mediante a admissão pelo Tribunal Regional Federal da 4a Região de sua condenação pelos crimes de corrupção passiva e lavagem de dinheiro.

Seguindo o ministro relator Luiz Edson Fachin, a maioria dos ministros votou no sentido da ausência de ilegalidade, abusividade ou teratologia (anormalidade) na decisão do Superior Tribunal de Justiça, que foi acionado logo após a negativa de habeas corpus pelo Tribunal Regional Federal da 4a Região, aplicando ao caso a atual jurisprudência do Supremo Tribunal Federal, que possibilita o início do cumprimento da pena após ratificação da condenação em segunda instância.

Ao votar pelo indeferimento do supramencionado habeas corpus, o ministro relator ressaltou que o entendimento dos tribunais deve ser estável e que, no caso da execução provisória da pena, ainda não havia ocorrido uma revisão da jurisprudência que permitisse esse tipo de prisão pelo poder concentrado. Para ele, tal alteração do entendimento sobre a antecipação de pena só pode ocorrer no julgamento de mérito das Ações Declaratórias de Constitucionalidade ${ }^{\circ}{ }^{\circ} 43$ e 44, o que veio a ocorrer somente no ano de 2019.

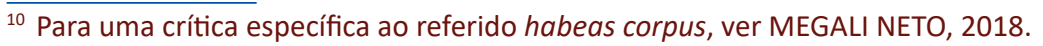




\subsection{O Princípio da Presunção de Inocência ou da Não Culpabilidade}

O princípio da presunção de inocência ou não culpabilidade vem inserido no artigo $5^{\circ}$, inciso LVII, da Constituição Federal de 1988, ao declarar que "ninguém será considerado culpado até o trânsito em julgado de sentença penal condenatória".

Com a promulgação da Carta Magna brasileira em 1988, que ficou conhecida como a Constituição Cidadã por trazer em seu texto inúmeras garantias após a ditadura militar, tem início uma série de discordâncias e fortes discussões doutrinárias acerca do supramencionado princípio constitucional. O debate tem como base a interpretação do novo princípio trazido no texto constitucional, estando de um lado os que entendiam que o texto dava a presunção de inocência ao acusado de cometer um delito penal e de outro uma corrente que defendia que o texto constitucional não tratava da presunção de inocência, mas sim da presunção de não culpabilidade.

Para Paulo Rangel, o que ocorre é uma declaração, afastando a ideia de que o texto constitucional estaria presumindo a inocência de alguém, mas sim declarando que ninguém poderá ser considerado culpado até o trânsito em julgado de sentença penal condenatória. Tal afirmação pode ser constatada quando o autor explica que

não adotamos a terminologia presunção de inocência, pois, se o réu não pode ser considerado culpado até o trânsito em julgado da sentença penal condenatória, também não pode ser presumidamente inocente. A Constituição não presume a inocência, mas declara que ninguém será considerado culpado até o trânsito em julgado de sentença penal condenatória (art. 5o, LVII). Em outras palavras, uma coisa é a certeza da culpa, outra, bem diferente, é a presunção da culpa. Ou, se preferirem, a certeza da inocência ou a presunção da inocência (RANGEL, 2010, p. 24).

Amilton Bueno de Carvalho (2001), por sua vez, tem um posicionamento diferenciado ao tratar o referido princípio como um pressuposto, pois mesmo que não estivesse positivado na Constituição Federal de 1988, ou até mesmo na Declaração Universal dos Direitos Humanos, continuaria sendo uma garantia fundamental por ser inerente ao próprio Estado de Direito. De acordo com o referido autor, o princípio da presunção de inocência não precisa estar positivado expressamente em nenhum lugar para que sua validade tenha de ser necessariamente reconhecida.

Em sentido semelhante, Aury Lopes Júnior (2016, p. 79) afirma que "a presunção de inocência impõe um verdadeiro dever de tratamento (na medida em que exige que o réu seja tratado como inocente), que atua em duas dimensões: interna ao processo e exterior a ele", referindo-se ao fato de que, segundo ele, o questionado princípio seria na verdade um dever, ou seja, o réu deve ser a todo momento, antes do trânsito em julgado, tratado como inocente, visando a evitar maiores danos ao acusado.

Com base princípio da presunção de inocência ou da não culpabilidade, podem ser observadas duas regras básicas.

A primeira é regra de prova, em que cabe a quem acusa o ônus de provar que o réu foi o responsável pelo delito. Por esse motivo, recai sobre o Ministério Público o papel de provar a existência de um fato que seja tido como criminoso e a autoria delitiva do ato, cabendo à defesa somente rebater as acusações com teses como a de excludente de ilicitude, excludente de culpabilidade ou até mesmo alegar causas de extinção da punibilidade. Concomitantemente a isso, tem-se o fato de que não cabe a aplicação da inversão do ônus da prova, uma vez que isso violaria a não culpabilidade constitucional do réu.

A segunda é a regra de tratamento, pela qual o suposto criminoso não pode e não deve ser tratado juridicamente como tal antes da sentença penal condenatória transitar em julgado. No sistema jurídico brasileiro há o que se chama de espaço de conformação legislativa para esse princípio, uma vez que seu texto abre margem para diferentes interpretações. A lei pode até vir a determinar que alguns efeitos jurídicos na esfera penal ocorram já durante o processo, contudo ela não pode ofender o núcleo essencial da presunção de inocência, colocando, assim, em xeque a sua existência como garantia fundamental.

Essa garantia é essencial nos dias de hoje, principalmente no Brasil, que teve direitos fundamentais suspensos durante um rígido regime militar que durou aproximadamente 20 anos. A presunção de inocência é um exemplo de direito conquistado diante das arbitrariedades e aos absurdos cometidos pelo Estado brasileiro em diferentes fases de sua História. Por essa razão, a jurisdição penal deve alcançar a efetividade de acordo 
com as garantias estabelecidas no texto constitucional, como forma de atender aos direitos dos réus e da própria população que se manifestou por intermédio do poder constituinte originário em prol da constituição de um Estado Democrático de Direito.

\subsection{Posicionamentos do Supremo Tribunal Federal Quanto à Admissibilidade da Prisão em Segunda Instância}

Antes de adentrar propriamente na mutação constitucional acerca da prisão em segunda instância, deve-se elucidar os próprios termos da discussão no Supremo Tribunal Federal. As Ações Declaratórias de Constitucionalidade $n^{\circ} 43$ e 44 tinham por objeto o artigo 283 do Código de Processo Penal brasileiro que, em seu caput, enuncia as hipóteses de cabimento da prisão do acusado antes e após o trânsito em julgado da sentença penal condenatória ao decretar que "ninguém poderá ser preso senão em flagrante delito ou por ordem escrita e fundamentada da autoridade judiciária competente, em decorrência de sentença condenatória transitada em julgado ou, no curso da investigação ou do processo, em virtude de prisão temporária ou prisão preventiva".

Para compreender o referido dispositivo é preciso distinguir, conforme ensina Rosmar Távora (2013), prisão penal de prisão processual. A primeira é oriunda de sentença penal condenatória transitada em julgado como resposta estatal ao delito ocorrido, ou seja, a real prisão satisfatória do direito de punir do Estado. Já a prisão processual ocorre no decorrer da persecução penal, isto é, a que não necessita da ocorrência do trânsito em julgado para ocorrer. É também conhecida como prisão cautelar ou provisória. Desse modo, não esteve em análise no julgamento no Supremo Tribunal Federal, ou mesmo está em questão nas atuais iniciativas legislativas da Câmara dos Deputados e do Senado Federal a possibilidade de prisão processual antes do trânsito em julgado, mas tão somente em relação à denominada prisão pena.

As dúvidas quanto a essa questão, dividindo opiniões no seio da sociedade e até mesmo no meio jurídico, estão relacionadas à interpretação do mencionado artigo $5^{\circ}$, inciso LVII, da Constituição Federal, ao enunciar que: "Ninguém será considerado culpado até o trânsito em julgado de sentença penal condenatória".

Essas indagações ganharam novos contornos em fevereiro de 2016, quando os ministros do Supremo Tribunal Federal decidiram, a partir de uma votação acirrada, que pessoas condenadas em segunda instância já poderiam ter suas penas antecipadas, e ganharam mais força por conta da decretação da prisão do ex-presidente Lula por ocasião da Operação Lava Jato. Antes, todavia, de firmarem esse juízo, entre os anos 2009 e 2016, prevalecia o entendimento de que os condenados teriam o direito de recorrer aos Tribunais Superiores em liberdade até que seus recursos se esgotassem.

Opiniões favoráveis - como a do ministro Luiz Fux - ao julgar as medidas cautelares nas Ações Declaratórias de Constitucionalidade $n^{\circ} 43$ e 44 , acreditam que os recursos às instâncias superiores possuem, muitas vezes, um caráter protelatório da decisão final. O referido ministro afirmou ainda que as decisões são atrasadas por "recursos aventureiros" e que o direito da sociedade de ver aplicada a lei penal está sendo abandonado. Dessa forma, argumenta que nesses casos, a prisão logo após a sentença condenatória em segunda instância seria mais justa.

A injustiça desses recursos estaria pautada no fato de que os réus condenados em segundo grau permaneceriam em liberdade por bastante tempo, podendo levar anos para que isso ocorresse. Logo, essa tese argumenta que a prisão após condenação em segundo grau é imprescindível para coibir a impunidade ou o arrastamento prolongado no cumprimento das penas, caracterizando, portanto, um fundamento marcadamente consequencialista, segundo o qual uma decisão deve ser tomada com base essencialmente em suas consequências, a despeito de seu conteúdo normativo. ${ }^{11}$

\footnotetext{
${ }^{11}$ Luis Fernando Schuartz (2008, p. 131) explica que há gradações no entendimento do consequencialismo jurídico, havendo desde a "posição que reserva à valoração das conseqüências da decisão um papel residual no referido juízo de adequação (quando, e. g., entender-se que a consideração das conseqüências somente deva entrar em cena se as técnicas jurídicas convencionais supostamente não forem capazes de reduzir o conjunto das decisões juridicamente adequadas a um único elemento, i. e., a uma única decisão correta), quanto aquela que admite, ao lado da análise conseqüencialista e com um peso maior ou menor no processo decisório, formas diferentes de argumentação (e. g., a que se ocupa em medir a "distância" da decisão ou de suas premissas daquilo que supostamente seria exigido pela interpretação gramatical de um dispositivo legal ou de um precedente paradigmático)."
} 
Como exemplo de tais argumentos, o ministro Luís Roberto Barroso cita, ainda, nos julgamentos das referidas medidas cautelares, situações em que o réu foi condenado em segunda instância e passou vários anos em liberdade ou sequer chegou a ser preso. Entre os citados, tem-se: o caso do jornalista Antônio Pimenta Neves, que matou a namorada, Sandra Gomide, pelas costas baseado em motivo fútil, passando-se quase 11 anos até que o mesmo fosse preso; o do ex-senador Luís Estevão, que foi condenado em 1992 por desviar R\$ 169 milhões de uma obra e somente após interpor 34 recursos aos Tribunais Superiores, levando cerca de 24 anos, em 2016 saiu o trânsito em julgado e o ex-parlamentar foi preso; o caso da prescrição do crime cometido pelo ex-jogador Edmundo, que ao sair de uma balada atropelou e matou 3 pessoas e foi condenado a 4 anos e meio de prisão, mas não foi preso em decorrência dos mais de 20 recursos interpostos ao Superior Tribunal de Justiça e ao Supremo Tribunal Federal.

Esses foram somente alguns dos exemplos citados pelo referido ministro para demonstrar que o cumprimento antecipado de pena evitaria a impunidade e até mesmo a ideia de que o crime pode vir a compensar. Esse pensamento pode ser identificado a uma mutação constitucional ativista e, portanto, conforme visto, inconstitucional, pois consiste em uma mudança abrupta do entendimento antes consolidado, o que contraria o núcleo de significado estabelecido pelo texto constitucional, afinal, a distinção entre texto e norma não significa que o intérprete possa estabelecer o Direito de maneira arbitrária, de acordo com o que sua consciência considera mais justo ou conveniente..$^{12}$

Alguns dos posicionamentos contrários à admissibilidade da prisão em segunda instância argumentam que o texto legal e o texto constitucional são explícitos no entendimento de que o réu deve permanecer em liberdade até o trânsito em julgado, ou seja, até que todos os recursos possíveis tenham sido julgados. Esse pensamento tem como base a ideia de que o dispositivo do Código de Processo Penal - objeto da análise de constitucionalidade - reproduz exatamente o princípio da não culpabilidade ou da presunção de inocência positivado na Constituição Federal, evidenciando, mais uma vez, o caráter paradoxalmente inconstitucional da mutação, pois não há como julgar inconstitucional um dispositivo legal que reproduz o teor da própria Constituição.

O mais estranho desse debate é que, conforme visto, o ativismo judicial é entendido geralmente como um instrumento para fazer valer os direitos das minorias em detrimento das maiorias, as quais, por definição, estão mais bem representadas no Legislativo e no Executivo. Dentro de uma perspectiva liberal que institucionaliza mecanismos de freios e contrapesos, o Judiciário deve exercer um papel contramajoritário de proteção dos direitos fundamentais a despeito de maiorias, ainda mais o Supremo Tribunal Federal, a quem a Carta Magna atribui no seu artigo 102 a tarefa de guarda da Constituição. Nesse caso, verifica-se o exato oposto, à medida que mesmo os direitos positivados no texto constitucional são flexibilizados judicialmente em razão das concepções pessoais de "justiça" ou de "efetividade", em afronta à supremacia normativa e à força normativa da identidade constitucional ainda vigente.

\subsection{O Julgamento do Supremo Tribunal Federal Sobre Prisão em \\ Segunda Instância em Sede de Controle Concentrado e Abstrato}

Após alguns anos desde o início do julgamento das Ações Declaratórias de Constitucionalidade 43 e 44, depois de quatro sessões de discussão, o pleno do Supremo Tribunal Federal decidiu, em 7 de novembro de 2019, alterar o entendimento que, desde 2016, permitia a prisão após condenação em segunda instância.

Por meio de uma maioria apertada, foram seis votos favoráveis à mudança, tendo votado nesse sentido os ministros Marco Aurélio Mello, Rosa Weber, Ricardo Lewandowski, Gilmar Mendes, Celso de Mello e Dias Toffoli, contra cinco defensores da permanência da jurisprudência que permitia esse tipo de prisão, sendo eles os ministros Luiz Fux, Alexandre de Moraes, Edson Fachin, Luís Roberto Barroso e Cármen Lúcia.

O relator das ações, o ministro Marco Aurélio, votou contrário às prisões antes do trânsito em julgado da sentença condenatória e sustentou ainda que os réus que se encontrassem presos nessa situação deveriam ser soltos, com exceção daqueles que possam ser alvo de prisões preventivas, que sejam presos perigosos ou que representem algum tipo de risco à sociedade.

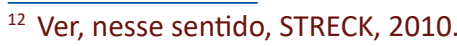


Os ministros Alexandre de Morais e Edson Fachin, que votaram pela improcedência das ações, argumentaram, respectivamente, que a medida não contraria o princípio da presunção de inocência, uma vez que a culpabilidade do acusado deve ser definida pelos juízes naturais, que são os juízes de 1a e 2a instâncias, e que, tanto o recurso especial, apresentado ao Superior Tribunal de Justiça, quanto o extraordinário, apresentado perante o Supremo Tribunal Federal, não têm poder de suspender os efeitos da condenação, defendendo assim a prisão mesmo havendo a possibilidade recursal.

Divergindo também do relator, Luís Roberto Barroso afirmou ser um atraso ao enfrentamento da violência e da corrupção tal mudança de entendimento, diante de todo o avanço ocorrido nos últimos anos e principalmente como resposta a essa "epidemia de violência e corrupção" que vem se alastrando pelo Brasil. Já a ministra Rosa Weber, que em um primeiro momento havia se posicionado a favor da prisão em segunda instância, mudou seu entendimento e seguiu o ministro Marco Aurélio ao afirmar que o texto constitucional é claro ao dizer que a prisão em caráter definitivo só poderia ocorrer após o fim da presunção de inocência, que só pode se dar após a prolação de sentença penal condenatória transitada em julgado.

O ministro Luiz Fux votou a favor da manutenção da prisão em segunda instância, elencando inúmeros casos emblemáticos como fundamento para sua decisão, como a morte da menina Isabella Nardoni, os casos de Elize Matsunaga, do goleiro Bruno e do jornalista Pimenta Neves, concluindo que o Direito não pode ser avesso à realidade dos fatos. Nesse mesmo sentido a ministra Cármem Lúcia afirmou que a alteração do entendimento poderia trazer a sensação de impunidade e de favorecimento das classes mais ricas do país.

Já os ministros Gilmar Mendes e Ricardo Lewandowski votaram contra a prisão antes do trânsito em julgado, fazendo com que o julgamento empatasse, deixando a decisão ao ministro Dias Toffoli.

Depois de inúmeras deliberações, o julgamento teve como voto de minerva o do então presidente da Corte, o ministro Dias Toffoli, que afirmou que seu voto não estaria analisando fatos, mas sim a concordância ou não do artigo 283 do Código de Processo Penal com a Constituição Federal, tornando a decisão do Supremo Tribunal Federal abstrata, ou seja, que não visa a beneficiar ninguém de maneira específica.

Em seu voto, afirmou que o texto do artigo alvo das ações representa a vontade do povo, uma vez que foi elaborado e posto no ordenamento jurídico brasileiro por aqueles que por ele foram eleitos, não cabendo ao juiz interpretar diferentemente desta vontade, pois, além de em conformidade com o desejo popular, encontra-se em consonância com o texto constitucional.

Nesse sentido, foi deferida a procedência das Ações Declaratórias de Constitucionalidade $n^{\circ 5} 43$ e 44 que colocam como marco para o início do cumprimento de pena de condenados a ocorrência do trânsito em julgado de seus processos, ou seja, somente após esgotados todos os recursos.

Diante, no entanto, das diferentes razões que justificaram o posicionamento de inadmissibilidade da prisão antes do trânsito em julgado da sentença penal condenatória, a controvérsia constitucional permanece. Conforme a síntese do argumento do ministro Dias Toffoli apontou, para alguns juristas a compatibilidade do artigo 283 do Código de Processo Penal com a Constituição Federal não significa necessariamente a impossibilidade de alteração da prisão em segunda instância por meio de uma iniciativa do poder Legislativo, seja mediante um projeto que altere a lei processual penal, ou mesmo de uma emenda à Constituição, esbarrando, por sua vez, esta segunda possibilidade na questão sobre em que medida essa alteração formal do texto constitucional violaria a condição de cláusula pétrea da presunção de inocência positivada no artigo $5^{\circ}$, inciso LVII. Caso essas iniciativas legislativas prosperem, o que significaria uma mutação constitucional por atuação do legislador, não se descarta uma reanálise da temática pela Corte Suprema, provavelmente com a participação de novos ministros.

Por essa razão, é fundamental o debate que ora se propõe sobre os limites da mutação constitucional como forma de evitar a perversão de um instituto que tem como finalidade preservar a supremacia e a força normativa da Constituição Federal. Os argumentos consequencialistas utilizados por alguns ministros para flexibilizar uma garantia de profundo sentido histórico para o Brasil consistem em ativismo judicial prejudicial aos direitos fundamentais enquanto núcleo básico do atual projeto constitucional brasileiro. 


\section{CONSIDERAÇÕES FINAIS}

Diante das pressões políticas e dos debates jurídicos em torno da flexibilização das garantias constitucionais na persecução criminal, o presente artigo analisou de que maneira a teoria jurídica configura determinados limites ao instituto da mutação constitucional, de modo a verificar em que medida eventuais mudanças de interpretação do Supremo Tribunal Federal acerca do princípio da presunção de inocência recai na prática de ativismo judicial. A hipótese inicial de pesquisa respondia afirmativamente a esse questionamento, apontando que a flexibilização da referida garantia fundamental contrariava o núcleo fundamental do modelo de Estado Democrático de Direito estabelecido pelo constituinte originário em 1988.

Para tanto, estudou-se inicialmente o conceito de mutação constitucional como forma de caracterizar seus aspectos essenciais. Foi possível elucidar que esse instituto consiste em um mecanismo de alteração informal da Constituição sem modificar o texto escrito, que visa a adaptar as normas constitucionais à realidade fática para preservar a força normativa da Constituição. Desse modo, a mutação constitucional carrega consigo uma tensão interna, pois autoriza uma transformação no sentido e no alcance das normas constitucionais para manter a eficácia de sua supremacia normativa. Isso indica que se, por um lado, a permanência da normatividade constitucional depende da atualização de seus sentidos a uma realidade em permanente transformação, por outro essa alteração não pode retirar a força normativa do núcleo fundamental da Carta que constitui o fundamento último de validade do ordenamento jurídico.

Essa conclusão parcial sobre o tema permitiu afirmar que a mutação constitucional deve observar os limites normativos concebidos pela própria Constituição para que o necessário ato de interpretação autêntica das normas constitucionais pelo Judiciário não configure um uso banalizado da prática de ativismo judicial, sob pena de violação dos preceitos fundantes do próprio Estado Democrático de Direito, que lhe confere legitimidade. Nesse momento do estudo foi apresentada a ideia de que a distinção entre texto e norma não significa que o intérprete esteja livre para atribuir qualquer sentido para a Constituição, sendo, portanto, os significantes contidos no artigo $5^{\circ}$, LVII, um limite fundante das possibilidades decisórias.

O trabalho chamou a atenção ainda para o fato de que o ativismo judicial praticado pelo Supremo Tribunal Federal no julgamento dos Habeas Corpus 126.292 e 152.752 contrariou seu próprio papel de guardião da Constituição. Em uma democracia constitucional ainda se justifica que o Judiciário adote uma postura ativista perante os demais poderes constituídos com a finalidade de proteger os direitos de minorias, à medida que o Executivo e o Legislativo possuem maior responsividade aos interesses majoritários. A flexibilização do princípio constitucional da presunção de inocência, contudo, viola exatamente os direitos fundamentais que devem ser preservados pela instituição que, frequentemente, avoca para si a condição de detentora da "última palavra" na interpretação constitucional.

Esse paradoxo revelou-se ainda mais intrigante quando se observou que a presunção de inocência é um pressuposto do próprio Estado de Direito e, como tal, constitui uma garantia fundamental a ser preservada mesmo que não estivesse positivada na Constituição Federal, o que evidentemente não é o caso, dado que o projeto constituinte de 1987-1988 buscou sepultar um longo período de suspensão dos direitos e garantias fundamentais. Tal constatação permitiu enunciar que a flexibilização de um mecanismo essencial para controle das arbitrariedades estatais por meio de uma mutação perverte o propósito básico deste instituto, cujo objetivo é preservar a força normativa e a supremacia da identidade constitucional. Em outras palavras, além de um ativismo, a mutação revela-se propriamente inconstitucional.

Por fim, o presente texto analisou a nova mutação ocorrida no julgamento das Ações Declaratórias de Constitucionalidade 43 e 44, nas quais o Supremo Tribunal Federal recuperou, em sede de controle concentrado, o sentido de presunção de inocência até o trânsito em julgado de sentença penal condenatória, destacando as justificativas dos votos favoráveis e contrários. A conclusão desse estudo aponta para os riscos de flexibilização do Direito e, sobretudo, de uma garantia fundamental ao Estado Democrático de Direito, com base em argumentos consequencialistas pautados em razões de segurança e de efetividade.

A relevância dessa tese pode ser comprovada na permanência desse debate na esfera pública brasileira, pois, talvez em razão da natureza de alguns dos argumentos utilizados na decisão anteriormente referida pela Corte Suprema, as casas legislativas federais têm se movimentado no sentido de realizar nova mutação e/ ou reforma constitucional acerca desta matéria. Não restam dúvidas, portanto, de que a retórica de combate 
ao crime e à impunidade continuará enxergando o Direito como óbice aos seus intentos autoritários. Desse modo, não basta ao constitucionalismo construir mecanismos institucionais para limitar o poder do Estado, é preciso que a academia jurídica exerça seu papel de crítica institucional como forma de controlar a perversão de institutos criados para a preservação do projeto democrático fundado em 1988.

\section{REFERÊNCIAS}

BARROSO, Luis Roberto. Curso de Direito Constitucional Contemporâneo: os conceitos fundamentais e a construção do novo modelo. 7. ed. São Paulo: Saraiva, 2018.

BARROSO, Luis Roberto. Judicialização, ativismo e legitimidade democrática. (Syn)thesis, Rio de Janeiro, v. 5, n. 1, 2012.

BENVINDO, Juliano Zaiden. A "última palavra”, o poder e a história: o Supremo Tribunal Federal e o discurso de supremacia no constitucionalismo brasileiro. Revista de Informação Legislativa, v. 51, n. 201, 2014.

BRASIL. Secretaria de Gestão Estratégica. Supremo Tribunal Federal. Estatísticas de ações do controle concentrado. Brasília, 2019. Disponível em: http://www.stf.jus.br/arquivo/cms/publicacaoBOInternet/anexo/estatistica/ControleConcentradoGeral/ CC_Geral.mhtml. Acesso em: 20 dez. 2019.

BULOS, Uadi Lammêgo. Mutação constitucional. São Paulo: Saraiva, 1997.

CARDOSO, Evorah Lusci; FANTI, Fabiola. Movimentos sociais e Direito: o Poder Judiciário em disputa. In: SILVA, Felipe Gonçalves; RODRIGUEZ, José Rodrigo (org.). Manual de Sociologia Jurídica. São Paulo: Saraiva, 2013.

CARVALHO, Amilton Bueno de. Lei, para que(m)? In: WUNDERLICH, Alexandre (org.). Escritos de Direito e Processo Penal em homenagem ao professor Paulo Cláudio Tovo. Rio de Janeiro: Lumen Juris, 2001.

CERQUEIRA NETO, José Nunes de. Como pensam os ministros do STF? Direito, política e guarda da Constituição no pós-1988. 2016. Dissertação (Mestrado) - Universidade de Brasília, Brasília, 2016.

CLÈVE, Clèmerson Merlin; LORENZETTO, Bruno Meneses. Mutação constitucional e segurança jurídica: entre mudança e permanência. Revista de Estudos Constitucionais, Hermenêutica e Teoria do Direito, v. 7, n. 2, 2015.

COSTA, Alexandre Araújo. Direito e método: diálogos entre a hermenêutica filosófica e a hermenêutica jurídica. 2008. Tese (Doutorado) - Universidade de Brasília, Brasília, 2008.

GARCIA, Ísis de Jesus. Uma Torre de Babel chamada Constituição Federal: reflexões a respeito do direito contemporâneo. 2008. Dissertação (Mestrado) - Universidade Federal de Santa Catarina, Florianópolis, 2008.

HESSE, Konrad. A força normativa da constituição. Trad. Gilmar Ferreira Mendes. Porto Alegre: Sergio Antônio Fabris, 1991.

KELSEN, Hans. Teoria pura do direito. Trad. João Baptista Machado. 7. ed. São Paulo: Martins Fontes, 2006.

LASSALE, Ferdinand. A essência da Constituição. 9. ed. Rio de Janeiro: Freitas Bastos, 2015.

LOPES JÚNIOR, Aury. Direito processual penal. 13. ed. São Paulo: Editora Saraiva, 2016.

MEGALI NETO, Almir. A relativização do princípio da presunção de inocência a partir da mutação constitucional no habeas corpus n. 126.292. Revice - Revista de Ciências do Estado, Belo Horizonte, v. 3, n. 2, 2018.

RAMOS, Elival da Silva. Ativismo judicial: parâmetros dogmáticos. São Paulo: Saraiva, 2013.

RANGEL, Paulo. Direito processual penal. Rio de Janeiro: Lúmen Juris, 2010.

RUFFIA, Paolo Biscaretti Di. Direito constitucional: instituições de direito público. Trad. Maria Helena Diniz. São Paulo: Revista dos Tribunais, 1984.

RUIZ, Yeraldin Arrieta. Populismo punitivo y Derecho Penal Simbolico. Revista Inciso, v. 20, 2018.

SARLET, Ingo; MARINONI, Luiz Guilherme; MITIDIERO, Daniel. Curso de direito constitucional. 7. ed. São Paulo: Saraiva, 2018.

SCHUARTZ, Luis Fernando. Consequencialismo jurídico, racionalidade decisória e malandragem. Revista de Direito Administrativo, n. 248, 2008.

SILVA, José Afonso da. Curso de direito constitucional positivo. 20. ed. São Paulo: Malheiros, 2002.

SOUZA NETO, Cláudio Pereira de; SARMENTO, Daniel. Direito constitucional: teoria, história e métodos de trabalho. 2. ed. Belo Horizonte: Fórum, 2017.

STRECK, Lenio Luiz. A diferença ontológica (entre texto e norma) como blindagem contra o relativismo no processo interpretativo: uma análise a partir do "ontological turn". Revista Brasileira de Estudos Políticos. Belo Horizonte, n. 89, 2004.

STRECK, Lenio Luiz. O que é isto - decido conforme minha consciência? 2. ed. Porto Alegre: Livraria do Advogado, 2010.

TÁVORA, Rosmar Antonni Rodrigues C. de Alencar. Curso de Direito Processual Penal. 8. ed. Salvador: Juspodivm, 2013.

TEIXEIRA, José Horácio Meirelles. Curso de direito constitucional. Rio de Janeiro: Forense Universitária, 1991.

VEGA, Pedro de. La reforma constitucional y la problematica del poder constituyente. Madri: Tecnos, 1999.

VIEIRA, Oscar Vilhena. Supremocracia. Revista Direito GV, São Paulo, v. 4, n. 2, 2008. 